\title{
EVALUATION OF BIODEGRADABILITY AND ENVIRONMENTAL IMPACT OF BIOWASTE LEACHATE
}

\author{
Monika Šabić*, Dajana Kučić Grgić*, Marija Vuković Domanovac* \\ * University of Zagreb, Faculty of Chemical Engineering and Technology, Zagreb, Croatia \\ corresponding author: Monika Šabić, e-mail: msabic@fkit.hr
}

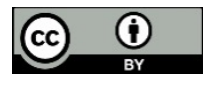

This work is licensed under a

Creative Commons Attribution 4.0

International License
Original scientific paper

Received: January $30^{\text {th }}, 2019$

Accepted: February $18^{\text {th }}, 2019$

HAE-1904

https://doi.org/10.33765/thate.9.1.1

\begin{abstract}
As the world's population and urbanization have significantly increased in the past few decades, the generation of municipal solid waste has accelerated on global scale. The biowaste disposal, which is an integral part of municipal waste, leads to leachate production. These kinds of wastewater are characterized by complex composition with very high concentrations of organic and inorganic pollution substances and toxicity, which may have harmful impact on the environment. This study investigated the physico-chemical and biological characterization of leachate from biowaste. The experiments were conducted in batch performance with initial concentration of leachate, expressed as chemical oxygen demand, $12.21 \pm 0.46 \mathrm{~g} \mathrm{O}_{2} / \mathrm{L}$ and $\mathrm{pH}$ value $4.05 \pm 0.13$. Obtained results showed that leachate from biowaste have high value of chemical oxygen demand, toxicity and low $\mathrm{pH}$. Overall efficiency of the process of aerobic biodegradation was $89 \%$. The abundance of viable bacterial cells and development of activated sludge flocs during the experiment confirmed the biodegradability of leachate from biowaste.
\end{abstract}

Keywords: leachate, biowaste, biodegradation

\section{INTRODUCTION}

As a result of rapid industrialization, population growth and urbanization, the trend of generation in municipal solid waste per person have significantly increased on global scale [1]. Primary disposal approach worldwide for this type of waste is landfilling [2]. Many developed countries have legal obligation to reduce the quantity of municipal waste sent to landfill, with particular emphasis on biodegradable waste. One of the main reasons for reduction of biodegradable waste in landfill is the leachate formation which represents significant pollution problems if it is not adequately controlled [3, 4]. Biodegradable municipal waste mainly comprises of biowaste which includes kitchen, garden or green waste from households, restaurants, caterers and retail premises, and comparable waste from food processing plants [5]. Composition of the leachate depends on the constituents of the wastes, moisture content, stage of biodegradation reached by the waste, the microbiota type, climatic conditions and the age of the landfill or 
operational procedures $[6,7] . \quad$ It is characterized by high organic load expressed as chemical oxygen demand (COD) value, toxicity, unfavourable odour and yellowish to dark brown colour [8].

Biological treatment is relatively simple, reliable, cost-effective and environmentally friendly method which can be used for treating wastewater with high organic loads [9]. Most commonly used biological treatment for wastewater is aerobic process with activated sludge, where microorganisms appear in flocs, mainly composed of bacteria [10]. Because of its origin, biowaste leachate is potential source of microorganisms. Thus, biological treatment with autochthonous microorganisms can be applied for the leachate contaminants degradation.

The aim of this research was to study physicochemical characterization of leachate from biowaste and to investigate its biodegradation potential by indigenous microorganisms which are naturally present in the leachate.

\section{EXPERIMENTAL}

In order to characterize the biowaste the laboratory simulation of leachate preparation was used. The biowaste consisted of 9 different biodegradable wastes (substrates) commonly found in households, as previously reported [11]. According to European standard EN 12457-4:2002 [12], the leachate from each individual substrate and biowaste was prepared by adding the material into distilled water in ratio $1 / 10$ and mixing it at $100 \mathrm{rpm}$ for 24 hours.

The biowaste for biodegradation process was mixed in mass ratios optimal for composting process [13]. Initial values of $\mathrm{C} / \mathrm{N}$ ratio, $\mathrm{pH}$ value and moisture content of biowaste mixture were $34 / 1,5.93$ and $57 \%$, respectively.

In order to assess the biodegradation process by the leachate's indigenous microorganisms, biodegradation experiments were carried out in batch performance on a rotary shaker at 160 rpm for 8 days, at room temperature $(23 \pm$ $\left.1^{\circ} \mathrm{C}\right)$. The experiments were conducted in 1000 $\mathrm{mL}$ Erlenmeyer flasks which contained 500 $\mathrm{mL}$ of biowaste leachate. Initial concentration of organic matter of leachate was $12.21 \pm 0.46$ $\mathrm{g} \mathrm{O}_{2} / \mathrm{L}$ expressed as chemical oxygen demand (COD). During the experiment, COD, biochemical oxygen demand (BOD), $\mathrm{pH}$ value, toxicity, mixed liquor suspended solids (MLSS), mixed liquor volatile suspended solids (MLVSS) and colony forming units (CFU) were monitored.

For each individual substrate physico-chemical characterization was conducted in means of determining COD and $\mathrm{pH}$ values. Physicochemical characterization of biowaste leachate was carried out at the beginning and at the end of biodegradation experiment. The $\mathrm{pH}$ value was measured by WTW Multi 340i set. COD was determined spectrophotometrically (Hach model DR/2400), MLSS and MLVSS were determined gravimetrically using Standard methods [14]. MLSS is an indirect measure of sludge concentration which is commonly used to characterize the biological mass in the activated sludge. MLVSS is a measure of the amount of volatile suspended solids found in a sample of MLSS. Variations in the concentration of MLVSS indicate a change in the amount of biomass share [9]. Biochemical oxygen demand (BOD) was determined by Winkler method and toxicity using bioluminescent bacteria Vibrio fischeri [15]. Bioluminescence inhibition assay has been widely used in determining toxicity of leachates [16]. Toxicity is expressed as the effective concentration of compound that affects $50 \%$ of bioluminescence inhibition $\left(\mathrm{EC}_{50}\right)$. When the sample is constituted by a mixture of compounds or contains unknown compounds, the result is expressed as percentage of sample that affects $\mathrm{EC}_{50}$ [17].

In order to monitor changes in biomass development, determination of CFU and microscopic analysis were applied. CFU of mesophilic bacteria and fungi were determined through preparation of decimal dilutions [11]. 
Microscopic analysis was performed using optical microscope (Olympus BX50) equipped with system for taking photographs (Olympus DP10 camera). Samples were microscopically examined under $100 \times$ total magnification.

\section{RESULTS AND DISCUSSION}

The results of physico-chemical characterisation of leachate from each individual substrate are shown in Figure 1. Average COD value of all biowaste leachate was $16.2 \pm 8.6 \mathrm{~g} \mathrm{O}_{2} / \mathrm{L}$, which correlates with the published results [18]. The highest COD value of $34.9 \mathrm{~g} \mathrm{O}_{2} / \mathrm{L}$ was obtained from leachate from apple peel, which consists of sugars (glucose, fructose and sucrose), cellulose and lignin [19]. $\mathrm{pH}$ value for all biodegradable leachates ranged between 4 and 7 , with average value of $5.5 \pm 1.0$.

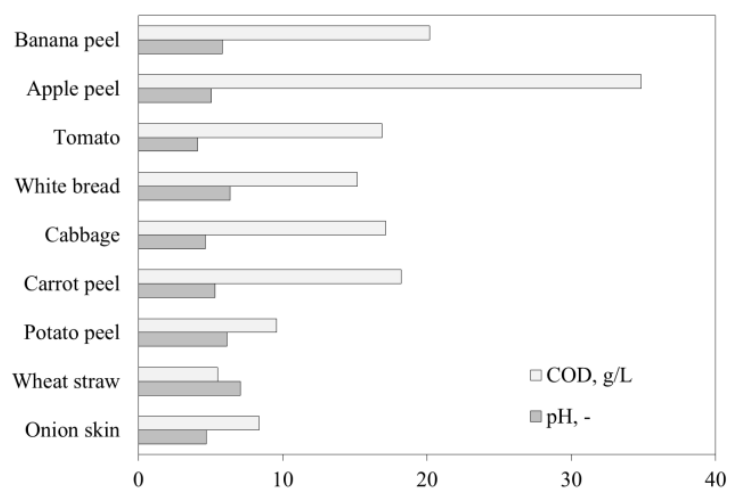

Figure 1. Physico-chemical characterization of leachate from each individual substrate

A biodegradation experiment was conducted for 8 days, in order to study the biodegradability of leachate from biowaste. At the beginning of the experiment $\mathrm{BOD}_{5} / \mathrm{COD}$ was 0.65 , which means that leachate is biodegradable and biological treatment can be applied.

Homogenizing and stirring conditions can promote microbial growth and enhance microbial degradation activity on pollutants from leachate [20]. According to Aktaş (2012) the ratio of initial COD to initial MLSS concentration is relevant in biodegradation process of organic compounds which are not easily biodegradable because of their inhibition effect. At the beginning of the experiment COD/MLSS value was 5.62 which correlates to the values found in literature [21]. From Figure 2 it can be seen that in $2^{\text {nd }}$ day of the experiment, value of COD/MLSS decreased for $46.7 \%$. High decrease of COD/MLSS value points out the major changes in COD and MLSS value, meaning the rapid growth of biomass due to utilization of dissolved organic matter from leachate. During the biodegradation experiment, COD gradually decreased while MLSS increased, indicating the development of activated sludge. MLSS/MLVSS ratio is a value often considered for evaluation of activated sludge activity [22]. Through biodegradation experiment MLVSS/MLSS ratio maintained relatively high with value of $0.89 \pm 0.02$ implicating that the amount of viable biomass in developed activated sludge is high. As the values of COD/MLSS ratio started to decrease from the day 6 to the end of experiment, the changes in MLVSS/MLSS values slightly followed the abatement trend. These changes occurred because of biomass decay due to decreased concentration of COD.

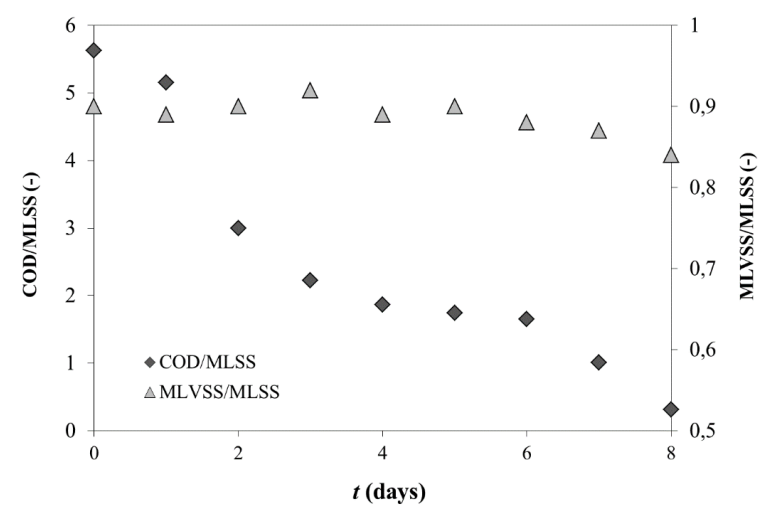

Figure 2. Changes in COD/MLSS and MLVSS/MLSS during 8 days in biodegradation process of leachate from biowaste

During the biodegradation experiment, changes in number of viable cells of bacteria and fungi were observed (Figure 3 ). The number of bacteria and fungi in $1 \mathrm{~mL}$ of biowaste leachate at the beginning of the experiment was $3.1 \times 10^{8}$ and $1.2 \times 10^{5}$, 
respectively. From the beginning to the third day of the experiment, the phase of exponential growth was observed, where the highest value of $\mathrm{CFU} / \mathrm{mL}$ of leachate $3.7 \times 10^{8}$ for fungi was obtained. The viable number of bacterial cells maintained till the end of the experiment with average value $3.4 \times 10^{9}$ while the number of fungi decreased to $1.7 \times 10^{7}$ $\mathrm{CFU} / \mathrm{mL}$. During the biodegradation process the total number of bacteria was in range of $10^{9} \mathrm{CFU} / \mathrm{mL}$, while in landfill leachate without biostimulation the number rages between $10^{3}$ and $10^{6} \mathrm{CFU} / \mathrm{mL}$ [23].

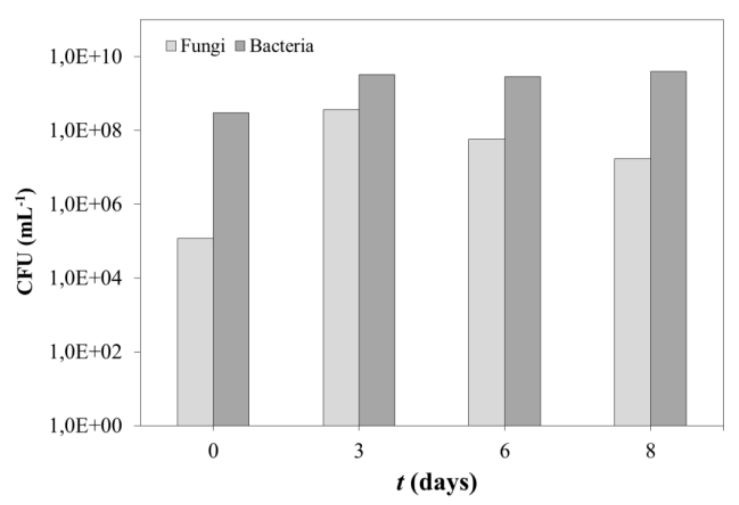

Figure 3. Changes in CFU for bacteria and fungi during 8 days in biodegradation process of leachate from biowaste

Physico-chemical characteristics of leachate from biowaste at the beginning and after the biodegradation experiment are summarized in Table 1. Biodegradable organic matter, in terms of BOD5/COD ratio, indicated high biodegradability of leachate from biowaste. As a result of biodegradation process, biomass developed and biodegradability decreased by $80 \%$, while overall removal efficiency of dissolved organic matter was $89 \%$ at the end of biodegradation process.

Table 1. Physico-chemical characteristics of leachate from biowaste at the beginning and at the end of biodegradation experiment

\begin{tabular}{|c|c|c|}
\hline Parameters & Initial values & Final values \\
\hline${\mathrm{COD}\left(\mathrm{g} \mathrm{O}_{2} / \mathrm{L}\right)}_{12.21 \pm 0.46}$ & $1.39 \pm 0.24$ \\
\hline $\mathrm{BOD}_{5}\left(\mathrm{~g} \mathrm{O}_{2} / \mathrm{L}\right)$ & $7.94 \pm 0.98$ & $0.18 \pm 0.02$ \\
\hline $\mathrm{BOD}_{5} / \mathrm{COD}(-)$ & $0.65 \pm 0.76$ & $0.13 \pm 0.11$ \\
\hline $\mathrm{pH}(-)$ & $4.05 \pm 0.13$ & $8.45 \pm 0.06$ \\
\hline $\mathrm{EC}_{50}(\%)$ & $6.45 \pm 0.17$ & $25.33 \pm 0.88$ \\
\hline
\end{tabular}

While biological wastewater treatment generally occurs at neutral $\mathrm{pH}$, in conducted experiment $\mathrm{pH}$ value changed from 4.05 to 8.45. Due to the decomposition of organic nitrogen in biodegradation process ammonium is released. Hence, the concentration of $\mathrm{NH}_{4}{ }^{+}$ is increased and $\mathrm{pH}$ value increases to alkaline range [24]. Optimum $\mathrm{pH}$ for bacterial growth is neutral $\mathrm{pH}$ area to slightly basic $\mathrm{pH}$, while optimal growth of fungi is in acidic environments [25].

In conducted experiment, leachate from biowaste was considered toxic according to $\mathrm{EC}_{50}$ values [16]. From Table 1 it can be observed that at the beginning of the experiment value $\mathrm{EC}_{50}$ was 3.93 times lower than the $\mathrm{EC}_{50}$ value at the end of experiment. This means that leachate at the beginning of the experiment consist of more toxic compounds than at the end of experiment. Despite its toxicity, biodegradation treatment was successfully used. Major changes in colour and odour appeared at the end of biodegradation process. Unpleasant, slightly acidic odour, correlates with low $\mathrm{pH}$ value at the beginning of the experiment. As the process was near to its end, the odour became more pleasant, because of the removal of organic matter, which also increased $\mathrm{pH}$ value. Due to development of activated sludge and degradation of organic matter the colour of leachate became darker.

Microscopic analysis was conducted in order to give insight in the course of the biodegradation process. The results of microscopic examination are shown in Figure 4. At the $2^{\text {nd }}$ day of the experiment, the flocs started to form. A great number of small sludge flocs, irregularly shaped, with open floc structure which is specific for young sludge [26] can be seen in Figure 4a. Transparent and loose flocs indicate development of new biomass during the biodegradation process [9]. In the biodegradation process, as a result of degradation of organic matter, microbial growth appears. From Figure $4 \mathrm{~b}$ it can be seen that in the $6^{\text {th }}$ day of the experiment the formed and compact flocs appeared, with floc shape 
specific for biodegradation process of biowaste leachate in batch conditions.

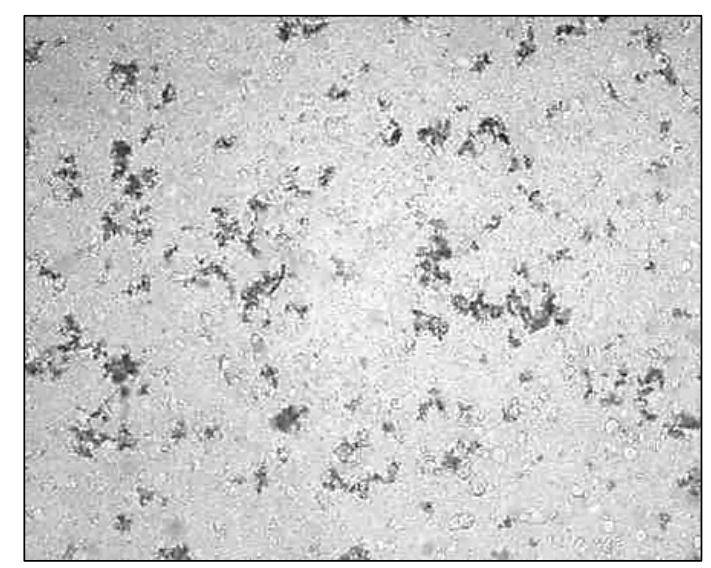

a)

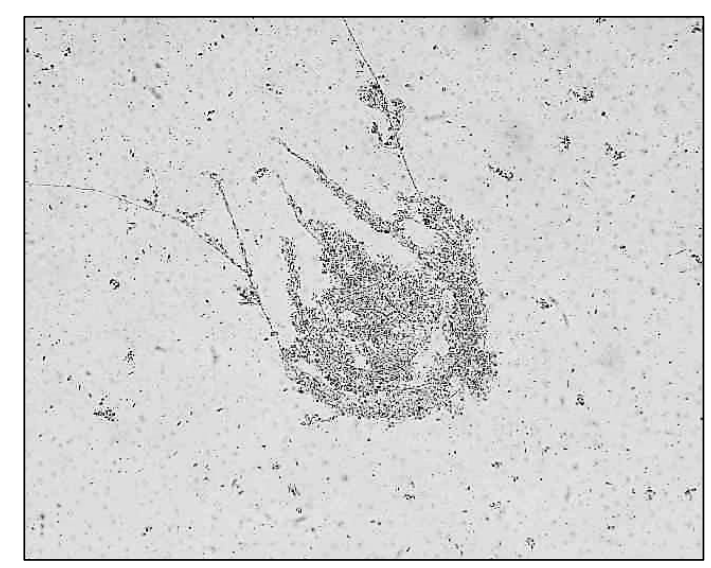

b)

Figure 4. Microscopic photographs of developed activated sludge flocs in biodegradation process of leachate from biowaste, magnification $100 \times$ : a) $2^{\text {nd }}$ day, b) $6^{\text {th }}$ day

\section{CONCLUSION}

Biowaste leachate is characterized by high organic load, toxicity and acidic $\mathrm{pH}$ value, thus treatment of leachate needs to be applied before its disposal to environment. The high value of biodegradability of biowaste leachate supported the concept of biological treatment application, which can also correlate to the application of composting process for treatment of solid biowaste. The process of leachate biodegradation was induced by aerobic conditions which led to removal of dissolved organic matter from biowaste leachate by naturally occurring microorganisms where COD/MLSS ratio was reduced for $94 \%$. As green technologies have gained more attention in field of environmental protection in recent years, biological treatment can be considered environmental friendly and cost effective technology.

\section{REFERENCES}

[1] R. Rajput, A.K. Chopra, Scenario of solid waste management in present Indian context, Caspian Journal of Environmental Sciences 7(2009) 1, 4553.

[2] Y. Chen, R. Guo, Y.-C. Li, H. Liu, T.L. Zhan, A degradation model for high kitchen waste content municipal solid waste, Waste Management 58(2016), 376-385.

[3] C. Romero, P. Ramos, C. Costa, M.C. Márquez, Raw and digested municipal waste compost leachate as potential fertilizer: comparison with a commercial fertilizer, Journal of Cleaner Production 59(2013), 73-78.

[4] A. Závodská, L. Benešová, B. Smyth, A.J. Morrissey, A comparison of biodegradable municipal waste (BMW) management strategies in Ireland and the Czech Republic and the lessons learned, Resources, Conservation and Recycling 92(2014), 136-144.

[5] http://ec.europa.eu/environment/waste/ compost/index.htm

Accessed: January 25, 2019.

[6] P.T. Williams, Waste Treatment and Disposal, $2^{\text {nd }}$ Edition, John Wiley \& Sons, Chichester, 2005.

[7] F.A. El-Gohary, G. Kamel, Characterization and biological treatment of pre-treated landfill leachate, Ecological Engineering 94(2016), 268274.

[8] M. Tamrat, C. Costa, M.C. Márquez, Biological treatment of leachate from 
solid wastes: Kinetic study and simulation, Biochemical Engineering Journal 66(2012), 46-51.

[9] M. Vuković, I. Ćosić, D. Kučić, N. Kopčić, F. Briški, Biodegradation Kinetics of Tobacco-waste Leachate by Activated Sludge in a Sequencing Batch Reactor (SBR), Chemical and Biochemical Engineering Quarterly 26(2012) 3, 191-198.

[10] M. Šabić, M. Vuković Domanovac, Z. Findrik Blažević, E. Meštrović, Kinetika bioremedijacije farmaceutske industrijske otpadne vode, Kemija u industriji 64(2015) 11-12, 229-236.

[11] D. Kučić Grgić, M. Vuković Domanovac, T. Domanovac, M. Šabić, M. Cvetnić, V. Ocelić Bulatović, Influence of Bacillus subtilis and Pseudomonas aeruginosa BSW and Clinoptilolite Addition on the Biowaste Composting Process, Arabian Journal for Science and Engineering 44(2019) 1, 111.

[12] EN 12457-4:2002, Characterization of waste - Leaching; Compliance test for leaching of granular waste materials and sludges - Part 4: One-stage batch test at a liquid to solids ratio of $10 \mathrm{l} / \mathrm{kg}$ for materials with particle size below 10 (without or with size reduction), European Committee for Standardization.

[13] S. Hemidat, M. Jaar, A. Nassour, M. Nelles, Monitoring of Composting Process Parameters: A Case Study in Jordan, Waste and Biomass Valorization 9(2018) 12, 2257-2274.

[14] APHA, Standard Methods for the Examination of Water and Wastewater, Washington, 2012.

[15] HRN EN ISO 11348-3:2010 Kvaliteta vode - Određivanje inhibitornog učinka vodenih uzoraka na emisiju svjetla bakterije Vibrio fischeri (Test sa svjetlećim bakterijama) - 3. dio: Metoda $\mathrm{u}$ kojoj se upotrebljavaju liofilizirane bakterije.

[16] P. Ghosh, I.S. Thakur, A. Kaushik, Bioassays for toxicological risk assessment of landfill leachate: A review, Ecotoxicology and Environmental Safety 141(2017), 259270.

[17] R. Idel-Aouad, M. Valiente, C. Gutiérrez-Bouzán, M. Vilaseca, A. Yaacoubi, B. Tanouti, M. López-Mesas, Relevance of toxicity assessment in wastewater treatments: Case study -Four fenton processes applied to the mineralization of C.I. Acid Red 14, Journal of Analytical Methods in Chemistry 2015(2015), 1-7.

[18] S.W. Van Ginkel, S.-E. Oh, B.E. Logan, Biohydrogen gas production from food processing and domestic wastewaters, International Journal of Hydrogen Energy 30(2005) 15, 1535-1542.

[19] N. Mirabella, V. Castellani, S. Sala, Current options for the valorization of food manufacturing waste: a review, Journal of Cleaner Production 65(2014), 28-41.

[20] L. Azzouz, N. Boudjema, F. Aouichat, M. Kherat, N. Mameri, Membrane bioreactor performance in treating Algiers' landfill leachate from using indigenous bacteria and inoculating with activated sludge, Waste Management 75(2018), 384-390.

[21] Ö. Aktaş, Effect of S0/X0 ratio and acclimation on respirometry of activated sludge in the cometabolic biodegradation of phenolic compounds, Bioresource Technology 111(2012), 98-104.

[22] J. Fan, F. Ji, X. Xu, Y. Wang, D. Yan, X. $\mathrm{Xu}, \mathrm{Q}$. Chen, J. Xiong, Q. He, Prediction of the effect of fine grit on the MLVSS/MLSS ratio of activated sludge, Bioresource Technology 190(2015), 5156.

[23] M. Matejczyk, G.A. Płaza, G. NałęczJawecki, K. Ulfig, A. MarkowskaSzczupak, Estimation of the environmental risk posed by landfills using chemical, microbiological and ecotoxicological testing of leachates, Chemosphere 82(2011) 7, 1017-1023.

[24] D. Kučić, M. Vuković Domanovac, F. Briški, Kinetics of aerobic treatment of two-phase olive-mill waste by activated sludge in sequencing batch reactor, 
Holistic Approach to Environemntmnt, 7(2017) 3, 139-155.

[25] G. Bitton, Wastewater Microbiology, $4^{\text {th }}$ Edition, John Wiley \& Sons, Gainesville, 2011.

[26] D. Eikelboom, Process control of activated sludge plants by microscopic investigation, IWA Publishing, London, 2000 .

\section{Acknowledgements}

This study has been supported by the Department of Industrial Ecology, Faculty of Chemical Engineering and Technology, University of Zagreb. 